\title{
Constrained integration in Latin America: analysis based on a twenty-first-century centre-periphery vision
}

\author{
Marcos Vinicius Chiliatto-Leite ${ }^{1}$
}

\begin{abstract}
The early twenty-first century in Latin America was characterized by a "pink tide", in which a reorientation of national policies produced positive social outcomes and changed both the regional order and the role of regional integration in the different countries. Alongside this process, the international economy provided relief from the external constraint, which meant that growth paths were not interrupted by balance-of-payments crises. Nonetheless, the progress made in regional integration falls well short of political intentions. This article posits that major transformations occurring at the centre of the international economy prevented the region's production structure from becoming more diversified. Unfortunately, as existing production structures were reproduced (or reprimarized), external engagement outside the region became deeper and Latin American integration remained constrained and confined to a secondary role.
\end{abstract}

\section{Keywords}

Economic development, economic integration, peripheral capitalism, regionalism, development models, productivity, economic dependency, international economic relations, Latin America, China

\section{JEL classification}

F14, F15, O14

\section{Author}

Marcos Vinicius Chiliatto-Leite holds a $\mathrm{PhD}$ in Economics and is Coordinator at the Secretariat of the Inter-American Development Bank (IDB). He previously served as Economic Affairs Officer at the Economic Commission for Latin America and the Caribbean (ECLAC). Email: chiliatto@iadb.org.

1 The views and opinions expressed in the text are the author's and do not necessarily represent those of the IDB Group. The author is grateful to Ricardo Carneiro for valuable collaboration. Naturally, any inaccuracies and other shortcomings in this essay are the author's exclusive responsibility. 


\section{Introduction}

In the early twenty-first century, Latin America lived through a political moment in which pragmatically-minded left-wing and centre-left movements gained power through democratic elections, in a process that has come to be known as the "pink tide". ${ }^{2}$ A "Latin Americanist" order, as distinct from the earlier Pan-Americanism, gained strength, expressing an integrationist rhetoric in different regional and subregional forums and agreements. This article analyses some of the reasons why Latin America has found it difficult to integrate regionally in terms of trade and production, despite political intentions.

During the pink tide period, Latin America was confronted by changes taking place at the centre of the international economy. The spread of financialization, the fragmentation and global redistribution of production, and the rise of China all combined to fuel a commodity boom, a fall in the relative prices of manufactured goods and abundant international liquidity. As a result of these changes at the centre of the global economy, Latin America's political context benefited from an easing of the external constraint, with the result that growth ceased to be hindered by the balance of payments, as it had been in various earlier periods. This easing of the external constraint was facilitated by low interest rates and by financial inflows from the centre of the international economy, in conjunction with a terms-of-trade shock (which, in this case, affected the subregions in different ways). ${ }^{3}$

Despite this political and economic context, progressive structural change did not occur in Latin America; and, as a result, it is argued that the region failed to integrate as advocated by the rhetoric propounded by its leaders. While many countries made progress on social inclusion and in reducing inequalities, the production structure did not become more diversified. The same factors that helped ease the external constraint, such as the liquidity cycle and the relative price shock, also played a key role in the production structure and even led to a reprimarization of the economy in some countries.

Understanding the characteristics of regional integration requires a joint analysis of production structures, viewing one element as a reflection of the other. The key to understanding the constriction of regional integration is the fact that existing production structures have been reproduced. The fragile regional integration of the early twenty-first century reflects the fact that the region has failed to build an integration-friendly production structure. The region's markets cannot absorb the primary commodities, or raw materials, produced by Brazil, Chile or Peru. The experiences of Europe, Asia and the North American Free Trade Agreement (NAFTA) show that regional integration goes hand-in-hand with integrated industrial production chains. Primary commodities have low levels of complexity and are generally destined for markets outside the region. This means that they have shorter and less fragmented production chains, with less capacity for regionalization. ${ }^{4}$

Differences in development patterns distinguish a Latin America to the north and another to the South. ${ }^{5}$ This article analyses the region in terms of the differences it displays in production structure, international position, the composition of aggregate demand and distribution, in a specific historical context. The conclusion is that, in the Southern part of Latin America, integration is difficult to envisage without a change in the commodity export structure. In the North, however, the production structure of the maquila industry is very closely bound to the United States economy; and the deepening of this strategy has also downgraded the priority assigned to regional integration. Based on this understanding of the link between the production structure and extraregional or regional relations, the article makes an analysis of the constriction of Latin American integration.

\footnotetext{
2 In an article published in the New York Times, Rohter (2005) described the election of Tabaré Vázquez in Uruguay as part of a widespread Latin American phenomenon, in which left-aligned governments were elected, often with anti-American discourses and representing a post-Washington Consensus period. The term "pink tide," rather than "red tide," evoked the pragmatic orientation of those left-wing movements that came to power and eschewed ruptures.

3 In a complementary way, domestic policies such as the accumulation of reserves, macroeconomic management with floating exchange rates and a change in the debt profile, among others, contributed to the easing of external constraints.

4 The topic of complexity has gained importance through the writings of Hausmann and others (2011). For a discussion of complexity and the structuralism view, see Chiliatto-Leite (2017) and also Gala, Rocha and Magacho (2018).

5 For an analysis of development patterns or styles - originating with Aníbal Pinto- see Bielschowsky (1998 and 2013).
} 
There are five sections, including this introduction. While section II deals with the pink tide and the Latin Americanist order, section III analyses China's relationship with Latin America. Section IV describes the key aspects of regional integration in Latin America, and section $V$ offers some final thoughts.

\section{The pink tide and the Latin Americanist order}

In the early years of the twenty-first century, several Latin American countries elected left-wing or centre-left governments, in a trend that came to be known as the "pink tide". Albeit with significant differences between individual countries, the region's political orientation distinguished that period from the 1990s, when the "Washington Consensus" held sway (Natanson, 2009).

This moment in the region's political history changed the understanding of regional integration and its role in development in region, the Americas and the world, in contrast to the situation in the late twentieth century. This section of the article discusses regional integration in its political dimensions, highlighting two fundamental elements: the formation of a new Latin Americanist order (distinct from the Pan-American vision) with political interests in forging greater regional integration, and the diversity of strategies in the region's different development patterns.

The pink tide had major effects on the international agenda and forums, and it defined a change of era. The "open regionalism" vision that had held sway in the 1990s was replaced by a new regional order which, albeit heterogeneous, had a Latin Americanist nature that differed from that of the earlier Pan-Americanism. This difference was expressed in various regional and subregional initiatives to promote economic and political rapprochement between the countries. ${ }^{6}$

After 2003, Brazilian foreign policy paid greater attention to Latin America and, in particular, to its southern portion (Almeida, 2004; Amorim, 2005). The Southern Common Market (MERCOSUR) was given new impetus, and emphasis was placed on the need to address structural asymmetries between members and the social issues on the agenda (Teixeira and Desiderá Neto, 2012). In 2004, negotiations were held between MERCOSUR and the Andean Community (CAN); and, in the same year, the new South American integration project, the South American Community of Nations (SACN), was launched. While this initiative focused on trade and infrastructure issues, it also sought greater political capacity and better representation in international forums. The agenda of the Latin American Integration Association (LAIA) was reiterated as the basis for promoting intrazone free trade, but it also went further. In the ensuing years, SACN attempted to establish a strategic plan and lines of action based on the goal of defining a common agenda. In 2007, SACN became the Union of South American Nations (UNASUR); and councils that reflected the integrationist, cooperative, political and developmentalist nature of the period became consolidated, in contrast to the "open regionalism" initiatives that had been driven by agreements on trade liberalization and regulatory convergence. ${ }^{7}$

Extending beyond South America, the first Summit of Latin America and the Caribbean on Integration and Development (CALC) was held in 2008, with participation by all of the region's 33 countries. In 2011, the Community of Latin American and Caribbean States (CELAC) was created by merging the Rio Group and CALC; and this served as a framework countering United States Pan-Americanism, since it excluded the United States and Canada, but did embrace Cuba (which remains excluded from the Organization of American States (OAS)).

The fact that countries had divergent development strategies did not prevent them all from meeting in CELAC. This grouping embraces Mexico, Central America and the Caribbean (which are more closely integrated with the United States) along with the South America of the pink tide. It is important to note that there were also other initiatives that cut across the South American space, such as the Bolivarian Alternative for the Americas (ALBA) and the PetroCaribe alliance.

\footnotetext{
6 Mota Veiga and Ríos (2007) examine 1990s regionalism - referred to by ECLAC (1994) as "open regionalism" - which emerged after the breakdown of "national developmentalism". In open regionalism, integration was subordinated to a broader liberalizing agenda.

7 For further details, see Calixtre and Barros (2011).
} 
Some countries had agendas that diverged from those of the pink-tide countries. For example, in addition to their agreements with the United States, Chile, Colombia, Mexico and Peru formed the Pacific Alliance in 2012, with the aim of deepening integration by progressively pursuing the free movement of goods, services, people and capital.

This early twenty-first-century shift marked the end of the greater liberal convergence and homogeneity of the 1990s, which spawned a new regional order with broader integration agendas. Teixeira and Desiderá Neto (2012) note the existence of an integrationist agenda and a new rhetoric around development, and argue that open regionalism was replaced by a "developmentalist regionalism". More cautiously, Bastos (2012) claims that the deepening of free trade agreements and the inoperability of collective mechanisms for managing imbalances, even within UNASUR, would suggest that proclaiming a post-liberal regionalism is an exaggeration, because the anti-liberal stance exists more in rhetoric than in practice. For Calixtre and Barros (2011), this is a historical moment following the crisis of neoliberalism -one which seeks to return to development pursued through regional integration. ${ }^{8}$

Notwithstanding the controversies, heterogeneous strategies clearly coexist, whereas the strategies of the neoliberal era coalesced more homogeneously around the Washington Consensus. The early twenty-first century saw signs of Latin American regionalism; and countries whose strategies continued to be based on subordinate engagement (pursuing ties with developed economies, with the prospect of greater asymmetrical integration) coexisted with those that were striving for a new regional geopolitical architecture, of a more developmentalist and regionalist hue. This implies a new regional order in which different models coexist.

Despite the new order, the results in terms of the integration of regional trade and production remain frustrating (as shown in section IV). It is therefore worth discussing some of the reasons why Latin America has intensified its extraregional relations while relegating regional integration to the background. The next section reviews a number of changes at the centre of the international economy.

\section{The new centre and peripheral Latin America in the early the twenty-first century}

In the early twenty-first century various changes took place at the centre of the international economy. The first is the advancing tide of financialization and the fragmentation of production chains, driven by large firms globally. The second is China's national development strategy and the rise of its economy to take a central role in production, trade and the generation of technical progress.

Chesnais (1995, 1996, 2003 and 2005), Epstein (2001), Belluzzo (1997), Tavares and Melin (1997), Plihon (2005), Aglietta and Rebérioux (2005), Aglietta (2006), Carneiro (2007), Palley (2007) and Guttmann (2008) analyse the topic of financial dominance, finance-dominated capitalism, globalized finance or the phenomenon of financialization. Late twentieth century capitalism has witnessed a predominance of the logic whereby the maximization of share values and dividend payments take precedence over any other objective of firms, workers and States. Gains for shareholders (who can easily sell their shares) in the shortest possible time are imposed as a top priority among the managers of the different corporations. Financial logic, therefore, subordinates and controls the production domain. The consequences of this process are analysed in various studies that address this issue. ${ }^{9}$

The key point is the preponderance of the goal of maximizing shareholder value, as the force driving the offshoring of production. Given the sovereignty of this goal, in conjunction with the liberalization of trade and capital flows, the intensification of international competition and the advent

\footnotetext{
8 Medeiros (2010) also proposes two theoretical-political paths for regional integration: "neoliberal" and "progressive".

9 Recently this process has given rise to the proliferation of financial derivatives, in which no physical delivery of goods is required, transactions are purely monetary, and there is no change in the ownership of the underlying assets. As Carneiro and others (2015) have noted, financialization is reaching a peak, as reflected in the inflated and more volatile prices of assets and commodities, the paths of exchange rates, interest rates, credit and the international financial crisis of 2008.
} 
of new communication and logistics technologies, large groups organized the offshoring of production and the creation of vast international subcontracting systems. This makes it possible to exploit a (sometimes highly) skilled labour force in countries with low or very low wages to produce goods and services for sale in advanced countries (Chesnais, 2005, p. 55). Duménil and Lévy (2005) found that foreign subsidiaries used these "subcontracting networks" to successfully maintain the profits and equity values of the firms that embarked on this process.

Milberg (2004) and Chesnais (2016) describe the relationship between financialization and the fragmentation of production chains; and Milberg (2004) notes the "coincidence" between the decline in manufacturing activity in various countries and the expansion of global value chains and outsourcing. Outsourcing and the fragmentation of value chains have enabled firms to increase shareholder returns, sometimes to the neglect of reinvestment in new production capacity.

Alongside this process, the Chinese economy grew exceptionally fast in the early twenty-first century and thus regained its position of international prominence (ECLAC, 2016a). Initially, this was linked to the geopolitical interests of the United States (Medeiros, 1999) and large-scale international industry outsourcing; but later it used the planning State to promote its own strategy of industrialization, urbanization, and development and to forge its sovereignty (Medeiros, 1999; 2006; Belluzzo, 2005; 2006; Carneiro, 2006; De Conti and Blikstad, 2017).

Initially a "peripheral" country, China founded its development on international trade and global value chains. Benefiting from flows of foreign direct investment (FDI) and trade, it thus complemented the strategy of the large international firms and the global production offshoring process; and in the early twenty-first century it showed signs of having become part of a central dynamic hub, rather than a satellite in the United States orbit. Although China continues to depend on United States growth, finance and currency and, partly, on imported technology in the most technology-intensive sectors, a new international economic hub has been created, of which it is a part; and this has major consequences for Latin America (Chiliatto-Leite, 2017).

In the twenty-first century, the meaning of "centre" or "centre-periphery" is based on analytical pillars that invoke production and technology issues, the spillover effects from the centre to its periphery and the role of currency in the international monetary system. It also depends on financial capacity, the political-military condition of the centre and the degree of structural heterogeneity of its economies. On this conceptual basis, there is much discussion about the conditions under which China rose with some (but not all) of the characteristics of the centre (Chiliatto-Leite, 2017). Based on this general understanding, this section describes the typical relationship of the centre-periphery relations between China and Latin America, highlighting the following aspects: (i) the capacity to boost the region's growth with spillover effects; (ii) the trade and production relationship; and (iii) financial flows (in particular FDI). An understanding of China's relationship with Latin America and its specific production structure will make it possible to analyse the deepening of extraregional integration and the difficulties of integration within the region.

The aim is to understand how changes in the centre, specifically the China link, have affected one part of the periphery, Latin America. While the international commodity and liquidity cycles generated in the centre eased Latin America's external constraint (Medeiros, 2015), they also served to reproduce its existing production structures (ECLAC, 2012). The formation of this new centre and the reproduction of the production structures in the region's development patterns are at the core of hypotheses that seek to explain the difficulties of Latin American regional integration in this study. ${ }^{10}$

\footnotetext{
10 For the United States view of China's rise in Latin America, see Gallagher (2016). This article examines the new central player (China) and leaves the traditional centre (the United States) in the background. However, China is advancing into trade, financial and political spaces that were traditionally occupied by the United States; and Chinese bilateral financing already outweighs flows from the multilateral banks led by the United States (Gallagher, Irwin and Koleski, 2012).
} 
The first strand of the argument that China built a new centre-periphery relationship with Latin America is that country's capacity to radiate growth through spillover effects. According to data from the International Monetary Fund (IMF), in 2015 China accounted for 15.5\% of global gross domestic product (GDP) and more than $230 \%$ of the GDP of Latin America and the Caribbean. In addition to comparing the size of these economies, figure 1 displays the correlation between China's GDP growth and that of various Latin American countries, which generally increased in the different groupings, albeit with varying intensity. The main differences reflect development patterns, in terms of the production structure and international position, so they were affected differently by the expansion of Chinese demand and by commodity prices, as reflected in the correlation between growth paths. ${ }^{11}$

Figure 1

China, United States and Latin America (selected countries): ${ }^{a}$ GDP correlations, 1980-2015

(Rolling averages, 10 years of annual growth, in percentages)

A. Correlation between China's GDP and that of southern Latin American countries

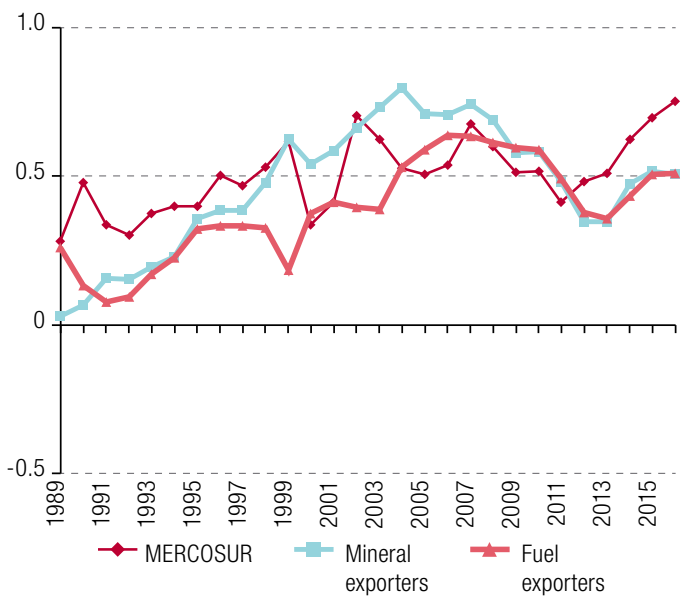

C. Correlation between China's GDP and that of northern Latin American countries

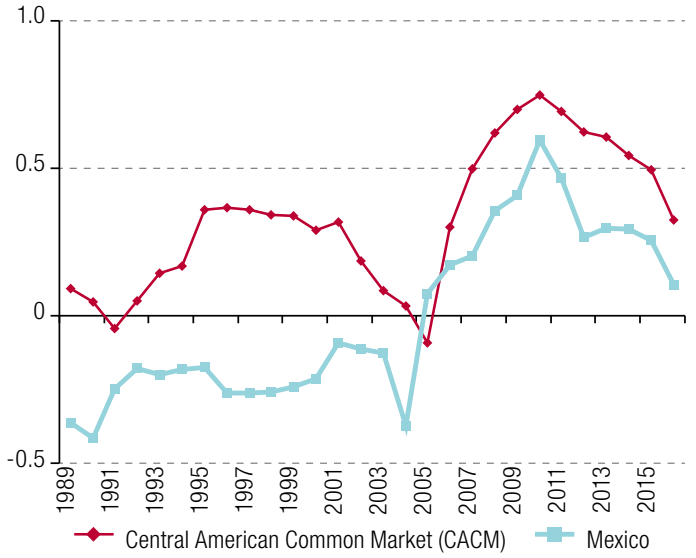

B. Correlation between the GDP of the United States and that of southern Latin American countries

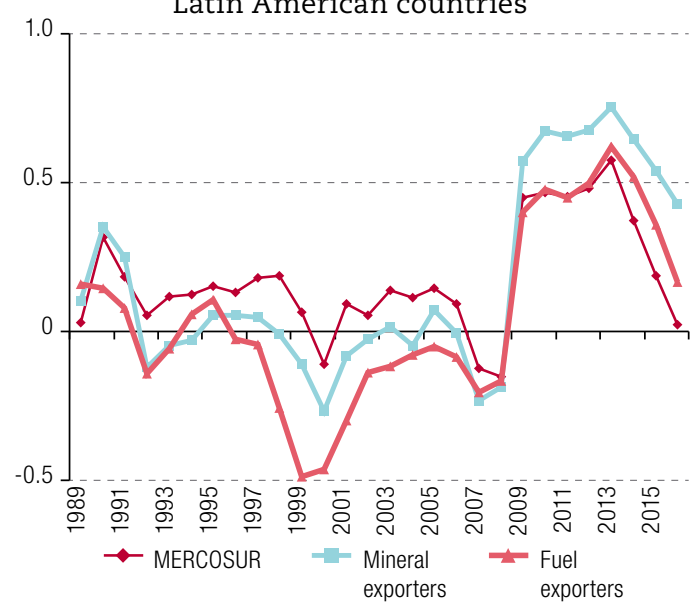

D. Correlation between the GDP of the United States and that of northern Latin American countries

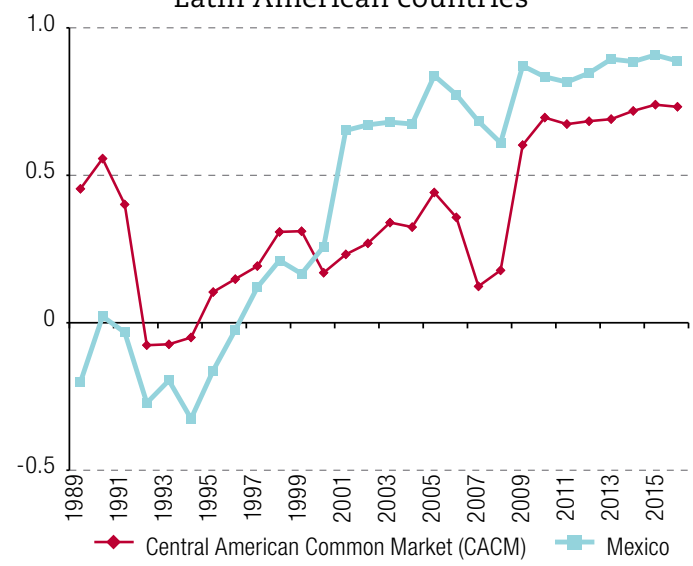

Source: Prepared by the author, on the basis of International Monetary Fund (IMF).

a Southern Common Market (MERCOSUR): Argentina, Brazil, Paraguay and Uruguay; Mineral exporters: Chile, Peru; Fuel exporters: the Bolivarian Republic of Venezuela, Colombia, Ecuador and the Plurinational State of Bolivia); and Central American Common Market (CACM): Costa Rica, El Salvador, Guatemala, Honduras and Nicaragua.

\footnotetext{
${ }^{11}$ Although it is well known that correlation is not causation, it does serve as a pointer in the debate, in which these data are presented in an analysis that combines both theoretical and historical elements to construct an argument.
} 
In the southern Latin American countries particularly, the stronger correlation with the growth of Chinese output has been relatively homogeneous and clear. Both in the MERCOSUR countries and in the mining and fuel-exporting countries, the correlation with China has strengthened significantly, even though the 2008 crisis generated a good deal of noise in the indicators. This crisis, which had its epicentre in the United States, spread worldwide and caused growth in most countries to collapse, after which the correlation became high and positive. While the correlations with China increased, those between southern Latin America and the United States displayed relatively haphazard or even declining paths compared to the pre-crisis period.

In the northern countries of Latin America, the correlation with China is also increasing, but with a different profile from that of the South. In Mexico specifically, the correlation strengthened during the commodity boom, owing to indirect spillover effects (derived either from commodities or from other countries that grew alongside China), since China's relations with Mexico did not develop as robustly as in the South. In the Central American countries (Central American Common Market (CACM)), although the correlation with China generally increased over the period, there were significant differences between the individual countries (which are concealed in the average shown in figure 1), and the path was not homogeneous.

The differentiation between the countries of the North (Central America and Mexico) and the South in the correlation analysis sheds light on the former's relationship with the United States. In the case of Mexico, the increase in correlations with the United States is clear to see, and reflects the deepening of integration after NAFTA in the 1990s. Correlation rates in Central America were also consolidated at high levels, as most countries became more closely integrated with the United States.

The effects of the growing importance of Chinese output growth on the region's countries are similar to those obtained by Cesa-Bianchi and others (2011), who made estimates for some of the region's largest economies (Argentina, Brazil, Chile, Mexico and Peru) in 1980-2010. According to these authors, this likely stems from the greater depth of the region's trade and production relations with China; but it is also seen as an indirect result of commodity prices or China's deeper relations with Latin America's traditional partners (such as the United States and Europe), which probably transmit the Chinese cycle to the region. Moreover, in the case of Mexico, the indirect effects are more prevalent than in the other countries, reflecting differences in development patterns and in the economies' international engagement.

The second aspect to be highlighted in a putative centre-periphery relationship with China concerns the region's trade patterns with that new participant in the central economy. The reproduction of existing production structures (ECLAC, 2012) reflects a deepening of relations between the region and China, which has become a dynamic hub. According to ECLAC (2016c), in Latin America's development patterns, the technological-intensity profile of trade relations changes according to the geographical destination of the products, such that in many cases regional trade has a higher technological content than trade outside the region, while the opposite is the case in relations with Asia.

The quality of the relationship between China and Latin America is similar to the traditional model of centre-periphery relations - that is an asymmetrical trade pattern in which Latin America (especially the South) imports more technology-intensive manufactures and exports commodities. ECLAC (2016c) highlighted the asymmetry of this trading relationship, in which Latin America exports a small number of natural-resource-based products while purchasing a wide range of products of higher technological content. Given this profile, the difference in the relationship between the countries of the north and south of Latin America and China is not surprising, because the Southern countries export commodities, whereas the north buys inputs for its maquila and competes directly in the United States market with the final product manufactured in Asia.

The third key feature of China's relationship with Latin America - and is also related to the quality of the trade and production relationship - is FDI flows. China is striving to consolidate its position in the regional (and global) financial architecture; and it is pursuing a strategy of expanding bilateral and 
multilateral credit operations in Latin America, which are also typical features of a centre economy relative to its periphery. ${ }^{12}$ From this standpoint, it seems clear that China has expanded its influence in the region and is now a major player.

ECLAC (2016c) made its own estimates to obtain a more accurate notion of the real importance of Chinese FDI flows to Latin America. Although there are many dimensions to this debate, the estimates objectively highlight the magnitude and profile of the flows, which are concentrated in natural resources.

Between 1990 and 2009, Chinese FDI flows to the region totalled about US\$ 7 billion. In 2010, the year of largest inflows, the figure was almost double the cumulative flow in that period, amounting to US\$13.7 billion (equivalent to $11 \%$ of total FDI flows to the region that year). In the ensuing years, from 2011 to 2015, FDI flows varied between US\$ 6 billion and US\$ 10 billion per year (about 3\% to $8 \%$ of total flows). In addition to the increased amount, the strategic profile of flows into the region is highly concentrated in natural resources. Nearly $90 \%$ of China's post-2009 FDI flows went to natural resources, whereas just 25\% of total FDI in Latin America and the Caribbean targeted this sector (ECLAC, 2016c). Flows from Chinese firms have therefore increased in the recent period and have been largely directed towards natural resources, thus reproducing the previous trade pattern and indicating China's clear strategic interest in Latin American commodities. ${ }^{13}$

To summarize these three typical elements of the centre-periphery relation, China has gained increased capacity to cause spillover effects in Latin America, so Chinese GDP growth has become more closely correlated with that of the region. China's trade pattern with Latin America is asymmetric and similar to the classic centre-periphery model; and there are increasing FDI flows from China to Latin America, concentrated in natural resources.

In addition to this classical centre-periphery pattern, there are major developments in the way Latin America relates to the central economies on the global scale, now reconfigured by the rise of China. One interesting feature concerns the prices of manufactures versus those of commodities, or the terms of trade. This has changed the challenges and "principal problems" that were discussed by Prebisch in the twentieth century, since, while commodity prices have trended up (between 2003 and 2011) and have been volatile, China has driven down the prices of manufactured goods, as will be discussed below. In addition to the classical features of the centre-periphery model, a new configuration can thus be seen in the centre of capitalism that has defined a new reality for peripheral economies in the twenty-first century.

One of the key elements of Prebisch's twentieth-century centre-periphery model was based on the fact that productivity growth in the industrialized countries was not lowering the prices of manufactured goods relative to commodities, so the neoclassical mechanism whereby the fruits of technical progress spread throughout the world failed to operate. Given the conditions of competition and the fact that profits and wages in the industrialized countries were sustained through successive business cycles, in the economies that led technical progress and controlled technology, the price of manufactured goods relative to raw materials did not fall over the years. Thus, the fruits of technical progress could not be transmitted to the peripheral countries (producers of commodities and consumers of manufactures). Unlike conventional theory, which postulates specialization based on comparative advantage, the fruits of technical progress were thus absorbed mainly in the centre.

\footnotetext{
${ }^{12}$ Aspects of the financial architecture, the construction of new development banks centralized in China and the growing volume of Chinese lending to Latin America are gaining increasing importance; and they are crucial in addressing the qualities that place China at the centre of the world economy more generally. This article only considers aspects related to FDI flows in more detail, owing to the limited space available.

${ }^{13}$ For further details on China's FDI strategy (both inward and outward), see OECD (2008) and Davies (2013). In a more recent study, De Conti and Blikstad (2017) note that, while FDI continues to flow predominantly to natural resources, there are also increasing flows and projects targeted on markets and profits. This may also reveal a strategy to create captive demand for Chinese inputs and capital goods in Latin American markets.
} 
It is curious that China displays the characteristics of a centre for Latin America; but given the global reorganization of production chains, in conjunction with Asian scale, productivity, logistics and low wages, the emergence of China in the new centre has also played a role in reducing the prices of manufactured goods. At the same time, it also fuelled an upswing in commodity prices, which then faded and revealed their volatility (leveraged and made even more volatile by financialization).

Ocampo (2007) and UNCTAD (2011) have described rising commodity prices in the long cycle; and Hiratuka and Sarti (2015) have reported falling prices among manufactured goods. Figure 2 displays the price indices of manufactures imported by the United States, which serve as an indicator of the declining trend in the prices of industrialized products on international markets. This information completes the argument that, while the early twenty-first century has witnessed upward and volatile pressures on commodity prices, those of manufactured products have indeed fallen.

Figure 2

United States: prices of imported manufactures, January 1994-December 2016

(Average index 1994=100)

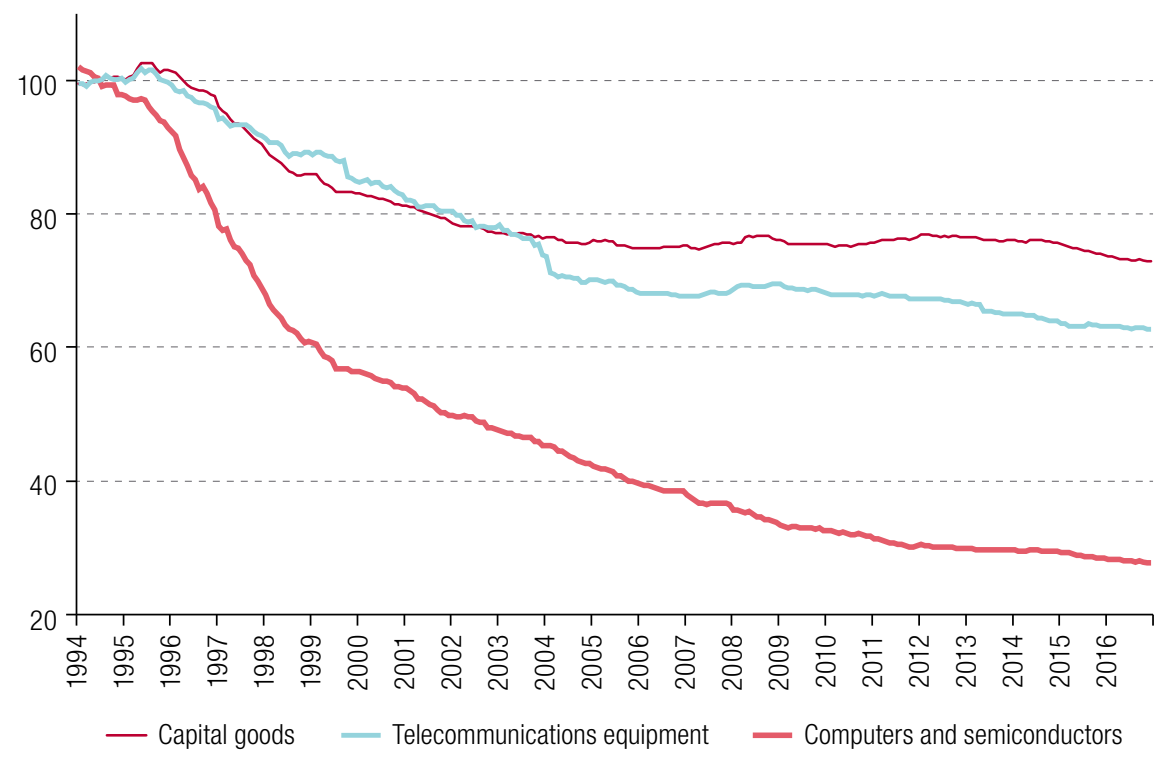

Source: Prepared by the author, on the basis of Bureau of Labor Statistics (BLS).

This change in the centre-periphery relationship does not mean that specialization in natural resources is now justified, because this would ultimately validate the argument that productivity increases can be redistributed from the centre to the periphery by reducing the prices of manufactured goods. There are several factors that continue to make commodity export specialization problematic. First, an analysis of value chains shows that these include stages with higher technology and knowledge content, which are difficult to replicate and therefore involve higher wages, and continue to be located in the central economies (Hiratuka and Sarti, 2015). Second, the rise in commodity prices relative to those of manufactured goods is not yet clearly established. With the end of the commodity cycle consolidated, the price trajectories of manufactured products and commodities need to be assessed more carefully to see whether more technology-intensive products have maintained their capacity to protect prices and incomes better than commodities. The sharp economic and income slowdown in commodity-producing countries suggests that the problem persists. Third, after 2014 it became clear that the new centre was in fact able to produce a cycle of rising commodity prices; and that commodity price trends, which are more prone to financial shocks, were more volatile and therefore persistently 
vulnerable to price-setting abroad. International trade data from the United Nations International Trade Statistics Database shows that manufacturing flows were larger and remained more dynamic even after the international crisis. This confirms that Latin America will remain at a disadvantage as long as commodity specialization persists.

Lastly, Gallagher and Porzecanski (2010) argue that China is threatening Latin America's manufactured exports both to the rest of the world and within the region itself. While China and the dynamics of the new centre have boosted demand for the region's exports and pushed up their prices, thereby fuelling foreign exchange inflows through trade, China has also captured manufacturing markets in Latin America and has fostered a reprimarization of the region through two channels - namely the incentive to invest in commodity-producing sectors (ECLAC, 2012; Rocha, 2015) and its high competitiveness and threat to Latin American manufacturing exports.

Gallagher and Porzecanski (2010) estimate the "threat analysis" based on the methodology developed by Lall, Weiss and Oikawa (2005). A direct threat is identified as when China gains a market share in exports of a certain product to a specific market at the same time as Latin America loses it; while a partial threat arises when China and Latin America both gain market shares but China expands more rapidly. Based on these two definitions, Gallagher and Porzecanski (2010) estimate that Chinese posed a significant threat to manufactured products in Latin America in 2000-2006. China either gained international and domestic markets that were previously served by Latin American manufactures, or else it outpaced Latin America in terms of selling manufactured goods (see table 1).

Table 1

Latin America: manufacturing exports "threatened" by China, 2000-2006

(Percentages)

A. Exports to the world "under threat"

\begin{tabular}{lccc}
\hline Country & Direct threat & Partial threat & Total \\
\hline Argentina & 37 & 59 & 96 \\
\hline Brazil & 20 & 70 & 91 \\
\hline Chile & 29 & 53 & 82 \\
\hline Colombia & 15 & 66 & 81 \\
\hline Costa Rica & 36 & 60 & 96 \\
\hline Mexico & 70 & 28 & 99 \\
\hline $\begin{array}{l}\text { Latin America and } \\
\text { the Caribbean }\end{array}$ & 62 & 31 & 94 \\
\hline
\end{tabular}

B. Exports to Latin America "under threat"

\begin{tabular}{lccc}
\hline Country & Direct threat & $\begin{array}{c}\text { Partial } \\
\text { threat }\end{array}$ & Total \\
\hline Argentina & 40 & 28 & 68 \\
\hline Brazil & 9 & 36 & 45 \\
\hline Chile & 28 & 64 & 91 \\
\hline Colombia & 21 & 47 & 67 \\
\hline Costa Rica & 27 & 69 & 95 \\
\hline Mexic0 & 32 & 46 & 78 \\
\hline
\end{tabular}

Source: K. Gallagher and R. Porzecanski, The Dragon in the Room: China and the Future of Latin American Industrialization, Palo Alto, Stanford University Press, 2010.

The rise of China as a central player in the global economy has boosted the demand for commodities; but it has also built a relationship that is more complex than the classical centre-periphery relations of the twentieth century. This is because it is also tending to lower the price of manufactured products, compete for manufacturing markets and make the task of diversifying production, with greater industrialization, much more difficult. In addition to the dramas of the past, the twenty-first-century centre-periphery approach has to face competition from low industrial prices in Asia and the consequent heightened risk of deindustrialization and reprimarization in economies that had succeeded in industrializing in the twentieth century, in a deeply financialized international economy with more volatile commodity prices. ${ }^{14}$

\footnotetext{
${ }^{14}$ Although this article does not enter into the deindustrialization debate, it draws on that rich literature, such as Rowthorn and Wells (1987), Palma (2005), Rocha (2015) and Rodrik (2016).
} 


\section{Latin American integration in the early the twenty-first century}

It is important to recognize the existence of regional heterogeneities within Latin America. In the north, the Mexican and Central American economies are characterized by industries with a high import content, serving demand from the United States; while production structures in the economies of the South are biased towards natural resources. Nonetheless in the large MERCOSUR countries the aggregate demand share of commodities (and of exports generally) is less than in the mineral-exporting countries (Chile and Peru) and those that export fossil fuels (the Bolivarian Republic of Venezuela, Colombia, Ecuador and the Plurinational State of Bolivia). The size of the different countries and the importance of their distribution path also vary in the different subregions. Moreover, the production structures and international positioning of the various development patterns did not change in the early twenty-first century - a period characterized by the transformation of central capitalism, increased financialization, the commodity price boom, the emergence of China as a central player in the international economy and the development of a centre-periphery relationship with Latin America, as described above. In short, while the characteristics of the maquila industry were maintained in the North, types of natural-resource dependency were preserved in the South. Furthermore, during this period political leaders tended to prioritize social issues and cherish the idea of changing production structures and increasing regional trade and production integration. However, despite making social progress, the region's production structure and its international position remained unchanged, so regional integration also failed to advance in consonance with the rhetoric.

The combination of the structural and integration issues completes the argument proposed here that integration objectives were not achieved and that integration was therefore constrained. Regional integration is evaluated from a trade and production standpoint using data on total trade, followed by value-chain indicators, using flows of value added and trade in intermediate goods.

There was clearly an absolute increase in total values traded at the regional level, with an interesting dynamic in which income growth, resulting from the expansion of activities linked to the export of commodities to the rest of the world, fuelled an expansion in regional trade, especially in manufactured products. This issue has been analysed by Hiratuka and Cunha (2011) for the specific case of Brazil. These authors note that apart from the growth in agricultural and mining exports, the expansion of international trade also indirectly affected Brazilian manufactured exports, because South American countries benefited from terms-of-trade gains and also started to import more manufactured goods from Brazil. This represents a procyclical effect of regional integration.

However, the results show a loss of relative trade share or, in some cases, very small growth. Thus, despite absolute growth, figure 3 shows that the region's relative share fell in nearly all of the selected development patterns.

In the southern part of Latin America, the absolute and relative growth of trade with China is the most salient feature, both in MERCOSUR and in the mineral- and fossil-fuel exporting countries. While growth in intragroup and intraregional trade increased considerably in absolute terms in the period under review, the total trade of these country groupings grew by more, so the relative importance of intragroup and intraregional trade declined. This reflects the fact that trade growth was mostly extraregional, while the increase in regional trade was secondary and procyclical relative to the growth of the economies in question, following a pre-existing structure of production and trade.

In the South, fossil-fuel-exporting countries were an important exception, with exports to MERCOSUR growing by more than total trade, thereby increasing the share of the Southern Cone countries. This reflects a number of specific influences, such as the growth of Bolivian gas exports to MERCOSUR. 
In the north of Latin America, where different production structures compete for the United States market with Asian manufactures, sales to China did not grow by as much as they did in the South. After the Central America-United States-Dominican Republic Free Trade Agreement (CAFTA) was signed, sales from the Central American Common Market (CACM) to the United States grew by more than total CACM trade with the world, so the relative share of the United States increased. In Mexico, the relative share of the United States slipped somewhat, but remained structurally high. The case of CACM is evidence of greater subregional integration, which continued to make headway in the early twenty-first century.

Figure 3

Latin America (selected countries): ${ }^{\text {b }}$ bilateral exports by country grouping, 2000-2015

(Percentages)

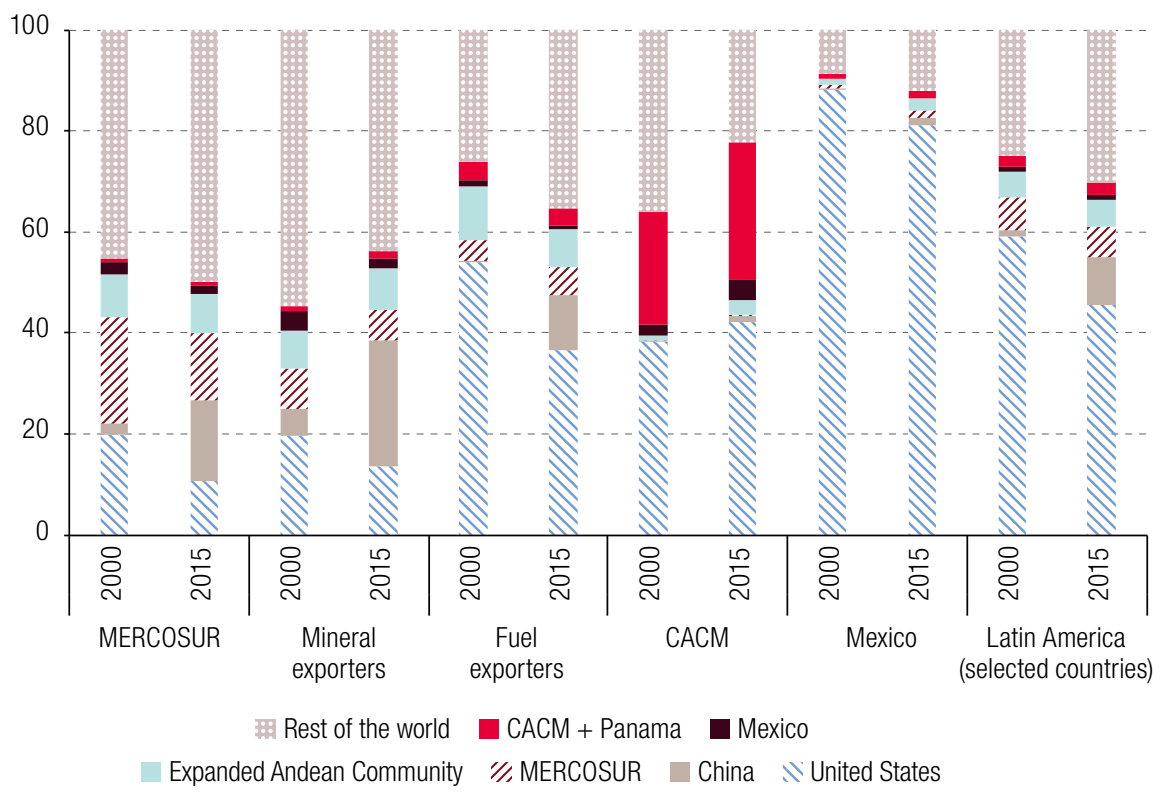

Source: Prepared by the author, on the basis of UN Comtrade - International Trade Statistics Database and R. Hausmann and others, The Atlas of Economic Complexity: Mapping paths to Prosperity, 2011 [online] http://www.tinyurl.com/lf8y4uw.

a Expanded Andean Community (CAN): the Bolivarian Republic of Venezuela, Chile, Colombia, Ecuador, Peru and the Plurinational State of Bolivia; (Latin America (selected countries): Southern Common Market (MERCOSUR) (Argentina, Brazil, Paraguay, Uruguay); mining countries (Chile and Peru); fossil-fuel-exporting countries (the Bolivarian Republic of Venezuela, Colombia, Ecuador, and the Plurinational State of Bolivia); Central American Common Market (CACM) (Costa Rica, El Salvador, Guatemala, Honduras, Nicaragua); and Mexico. Data for the Bolivarian Republic of Venezuela in the column for 2015 are taken from the 2014 Atlas. Data for Honduras in the 2015 column are taken from UN Comtrade 2014.

In addition to total trade, data on value added abroad in the upstream and downstream stages of global value chains should also be considered. Then, trade in intermediate goods (excluding commodities) need to be analysed to assess the region's participation in value chains both inside and outside the region.

The shares of Latin American value added in global exports (downstream) and the foreign value added contained in Latin American exports (upstream) indicate a consistently low regional share in global value chains in the early twenty-first century. Data for five of the region's countries (Argentina, Brazil, Chile, Colombia and Costa Rica) that have relatively more developed industries (Mexico is not included because its development pattern is associated with United States value chains) show that in 1995 these contributed less than $2 \%$ of value added in world exports and that, in 2011, the share in the later stages was just 3\% (ECLAC, 2016b). This generally weak participation in value chains is further aggravated by the fact that a substantial part of the region's value added in the later phases is commodity-based: in $2011,32 \%$ of the region's global value added was contributed by the primary sectors, compared to $17 \%$ in 1995. This growth is explained by the increase in demand and rise in prices. 
In the case of upstream content, the share of foreign value added in Latin American exports remained low compared to that of other world regions. Based on the same source, figure 4 shows that in 2011 just 13\% of the value exported by Argentina, Brazil, Chile, Colombia and Costa Rica was generated abroad, compared to 19\% in the NAFTA countries, nearly 30\% in the European Union and $32 \%$ in China.

Figure 4

Selected world regions: regional distribution of foreign value added contained in exports, 2011

(Percentages of exports)

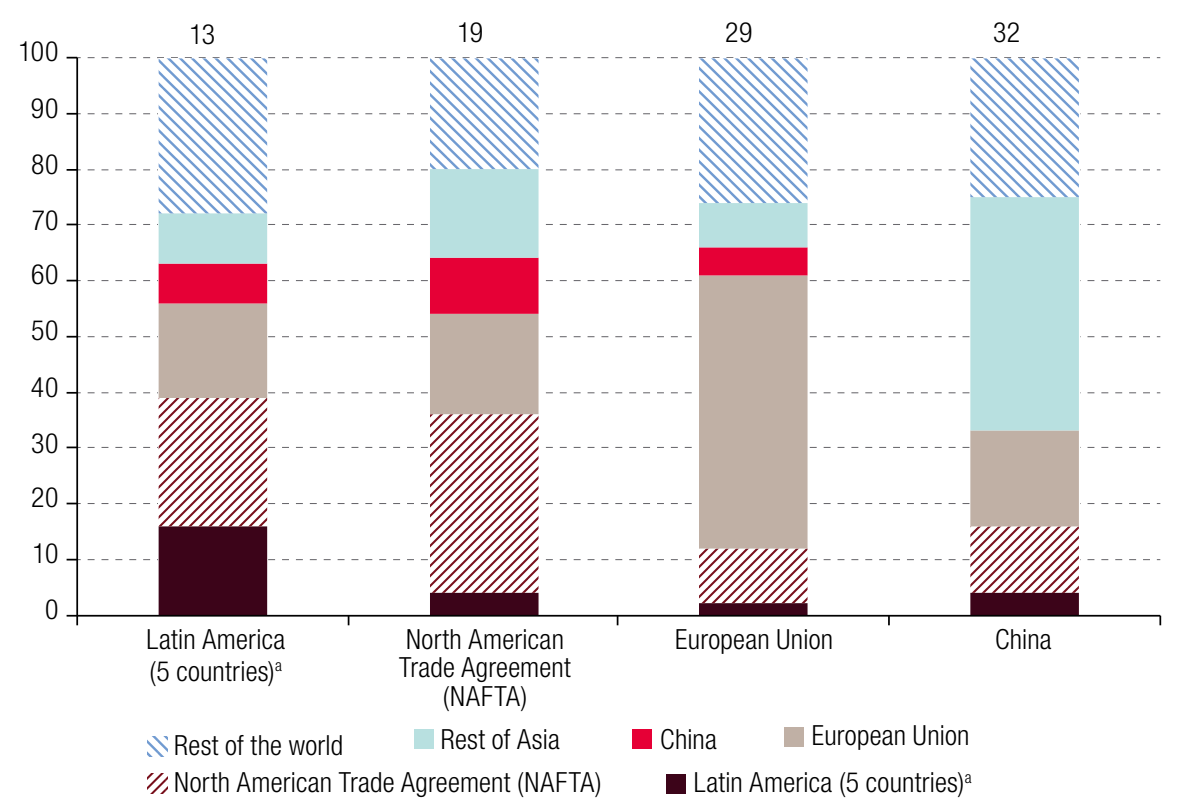

Source: Economic Commission for Latin America and the Caribbean (ECLAC), Latin America and the Caribbean in the World Economy, 2016 (LC/G.2697-P), Santiago, 2016.

Note: Share of world value-added in exports, preliminary phases (percentage shown at top of each column).

a Argentina, Brazil, Chile, Colombia and Costa Rica.

One of the characteristics of global value chains is their regionalization; and from this perspective too, Latin America lags behind other regions. In a world of fragmented production, the region does not participate massively in global and regional value chains and few value chains have been constituted in the region. Figure 4 shows that, of the meagre foreign value added contained in exports by Latin American countries (the $13 \%$ mentioned above), only $16 \%$ was generated within the region. In the rest of the world, the regional nature of value chains is evidenced by the fact that the intraregional share of export value added was 32\% in the case of NAFTA, $49 \%$ in the European Union and $42 \%$ in China.

Data on intermediate goods trade for the region as a whole reinforce observations based on the flows of value added contained in exports, which were limited to five Latin American countries. Figure 5 shows the values of intermediate goods trade (excluding commodities) for Latin America and the Caribbean, ${ }^{15}$ and also for NAFTA, the European Union and the Association of Southeast Asian Nations (ASEAN) plus China, Japan and the Republic of Korea, in order to compare the flow of intermediate goods trade within the country groupings. A greater flow of trade in intermediate goods within a region itself will indicate a higher prevalence of regional production chains. Figure 5 shows that Latin America and the Caribbean was the region in which value chains were the least regionally integrated of all of the selected groupings. In the region's trade in intermediate goods (excluding commodities), $23 \%$ of its exports were intraregional if Mexico is included and $32 \%$ if it is not; on the import side, those figures

\footnotetext{
${ }^{15}$ Based on ECLAC data prepared by Durán Lima and Zaclicever (2013), intermediate goods are defined according to the Classification by Broad Economic Categories (BEC), together with technological-intensity criteria. In practice, the database excludes commodities (which appear as "semi-finished intermediate goods" in another category) from the total number of intermediate goods.
} 
stood at $16 \%$ and $23 \%$, respectively. For comparison, in the European Union the equivalent flows were much larger than those of Latin America, at 65\% and 67\%, respectively. Similarly, in the group comprising ASEAN, China, Japan and the Republic of Korea, the figures were $55 \%$ and $58 \%$, while in NAFTA they attained $36 \%$ and $29 \%$, respectively.

\section{Figure 5}

Selected world regions: regional structure of trade in intermediate goods (excluding commodities) by destination and origin grouping, average 2010-2011

(Percentages)

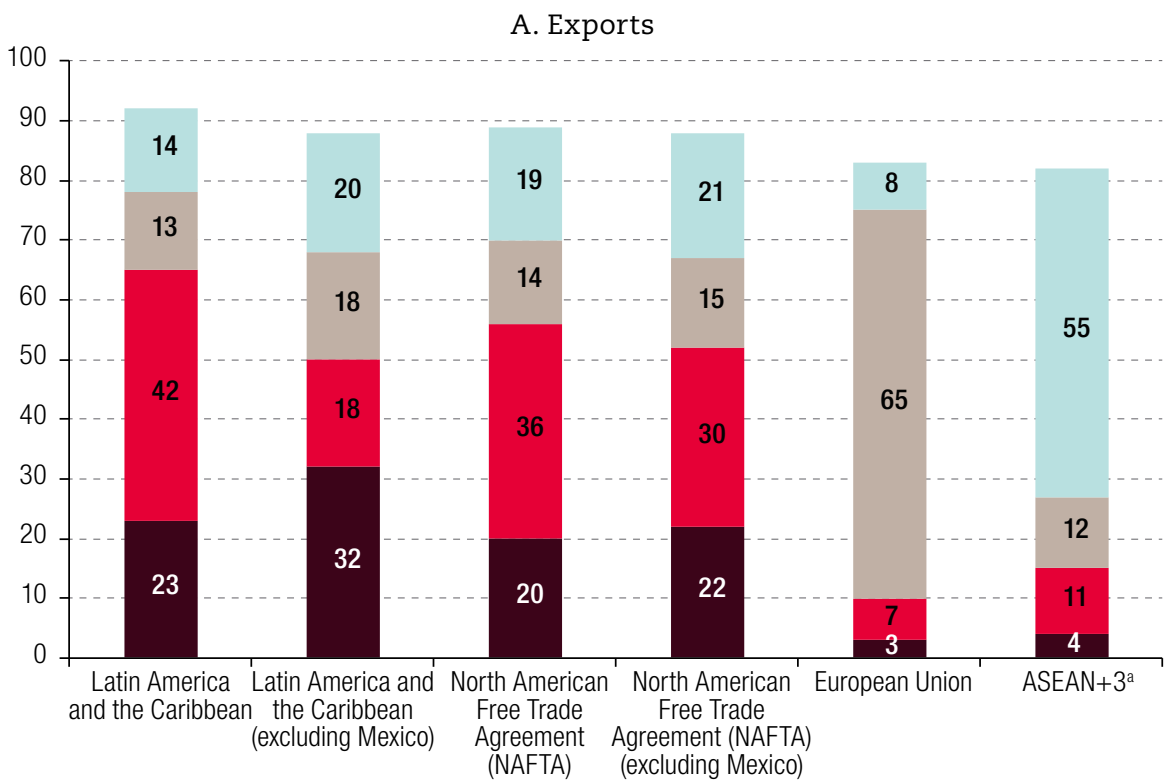

B. Imports

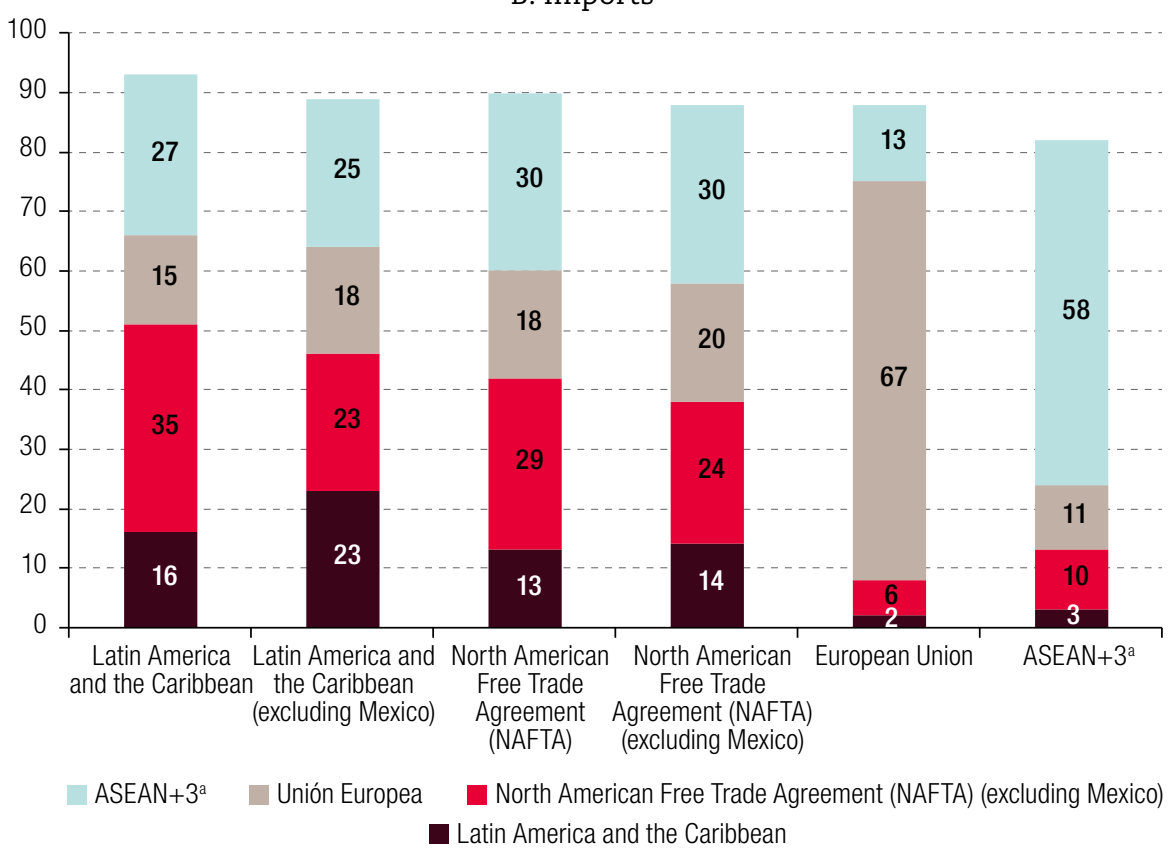

Source: Prepared by the author, on the basis of J. Durán Lima and D. Zaclicever, "América Latina y el Caribe en las cadenas internacionales de valor", International Trade series, No. 124 (LC/L.3767), Santiago, Economic Commission for Latin America and the Caribbean (ECLAC), 2013.

a Association of Southeast Asian Nations (ASEAN) plus China, Japan and the Republic of Korea. 
By disaggregating the region's share in intermediate goods trade by destination and origin (using the same concept of intermediate goods excluding commodities), figure 6 shows the structure of intermediate goods exports and imports by destination and origin grouping. Once again, the degree of regional and subregional integration is low; and it is clear that Latin America has generally kept its production structure more closely aligned to extraregional groupings than to regional ones.

Figure 6

Selected world regions: disaggregated regional structure of trade in intermediate goods (excluding commodities) by destination and origin grouping, average 2010-2011

(Percentages)

\section{A. Exports}

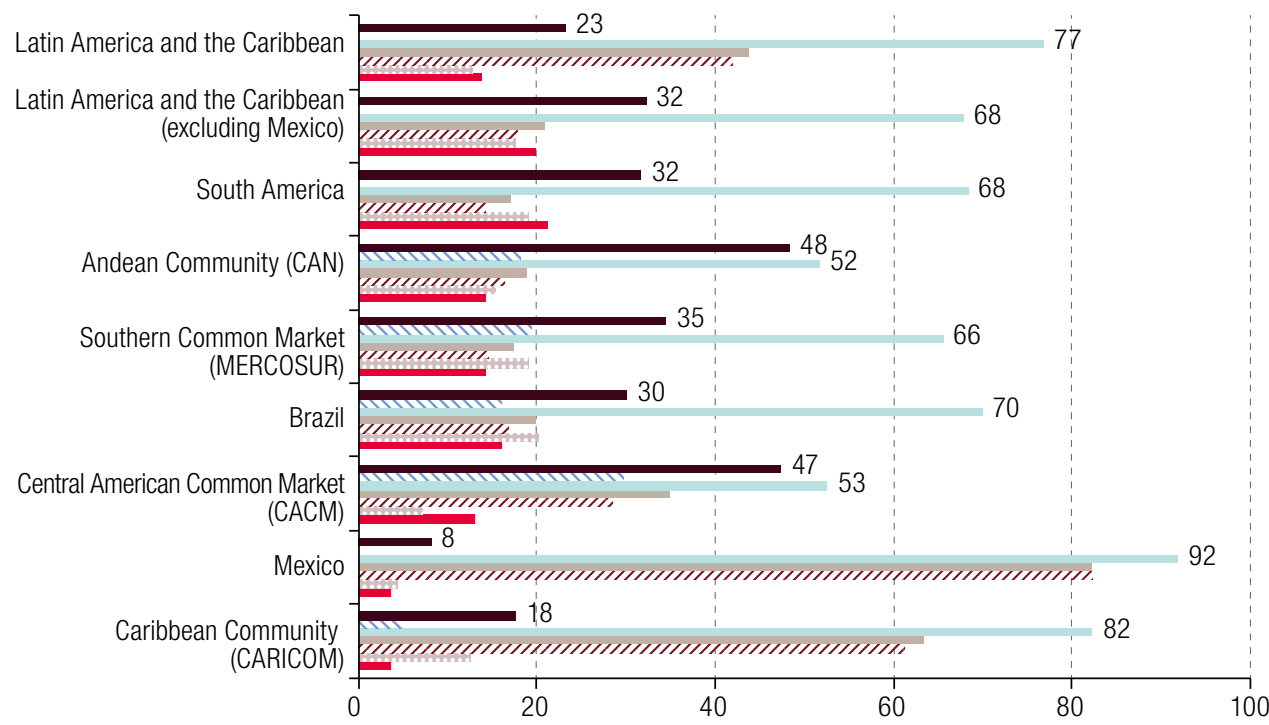

B. Imports

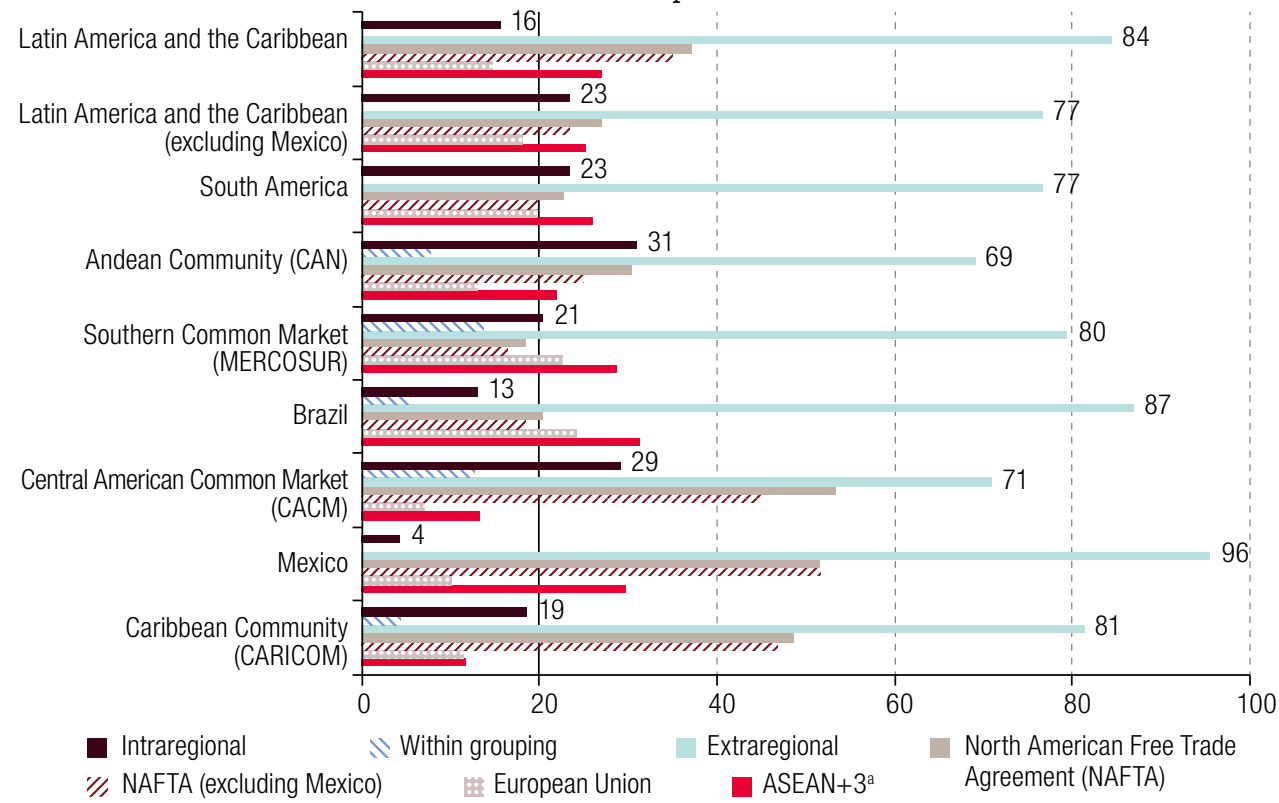

Source: Prepared by the author, on the basis of J. Durán Lima and D. Zaclicever, "América Latina y el Caribe en las cadenas internacionales de valor", International Trade series, No. 124 (LC/L.3767), Santiago, Economic Commission for Latin America and the Caribbean (ECLAC), 2013.

a Association of Southeast Asian Nations (ASEAN) plus China, Japan and the Republic of Korea. 
While Mexico has the highest rates of participation in extraregional value chains, the intermediate goods (exports and imports) of both the Andean Community and MERCOSUR in South America is also greater with extraregional groupings than within Latin America. This means that the historical pattern of participation in extraregional value chains or, in general, a deeper productive relationship with countries outside the region, is a structural feature that still endures. In the case of imports, the extraregional origin of intermediate goods is even more prevalent and reflects the fact that Latin America's production structures are less able to meet the demand for higher-technology parts and components and therefore have a greater need to source inputs from outside the region. These data show that it has been impossible to construct a new profile for trade and production integration in the region in the early twenty-first century.

Castilho (2012) argues that, while production integration is weaker in Latin America than in other regions of the world, the low transaction costs (reflecting geographical and cultural proximity) and the regional strategy pursued by some multinational firms have helped generate a considerable degree of production integration between neighbouring countries. Within MERCOSUR, Brazil and Argentina are the countries most deeply integrated in global trade flows in finished goods, parts and components. ${ }^{16}$ Moreover, part of the manufacturing industry of these countries has consolidated a significant degree of production integration, as exemplified by the automotive industry.

Also according to Castilho (2012), although Latin America is less integrated into global value chains than other regions of the world, the share of regional exports of components, parts and fittings in total exports is greater in regional sales. ${ }^{17}$ In other words, while production integration globally and regionally are relatively weak, it is greater at the regional level when measured as the share of total exports. This means that regional exports are more highly processed than extraregional ones and that the region's production integration is greater within the region than outside it (where commodity flows are substantial).

Castilho's conclusion (2012) is based on the weight of intermediate goods - parts, components and capital goods (also excluding commodities) - in total exports. Thus, when comparing the intermediate goods share of total exports, these extraregional flows are proportionately smaller, because commodity sales are much larger outside the region than inside it. Thus, using the data presented here, in conjunction with Castilho's conclusion (2012), a picture emerges of extraregional production integration which is more substantial in absolute terms, but, in proportion to total bilateral trade, reveals a greater relative share of intermediate goods at the regional level. This supports the idea that regional integration in industrial production chains could be deepened, and therefore regional flows of more technology-intensive intermediate goods could be increased in absolute terms.

Lastly, it can be argued that weak regional integration reflects the production structures that exist. The reproduction of commodity-intensive and less industrially diversified production structures, in the context of an international capitalism in which production processes are fragmented, has prevented further regional integration. The southern portion of Latin America displays a pattern of commodity- intensive or low-technology goods, which was stimulated by the commodity price boom; while the north of Latin America exports industrialized and more technology-intensive goods, but is productively integrated into United States value chains. Thus, Latin America's total regional trade and its intermediate goods trade cannot be at the same level as those of Europe, the group formed by ASEAN plus China, Japan and the Republic of Korea, or NAFTA. In contrast to Latin American development patterns these three groupings have succeeded in developing regional industrial value chains that are more technology-intensive and hence more regionally integrated. Commodities produced in the South cannot be absorbed by markets in the South, so they are sent to markets outside the region.

\footnotetext{
${ }^{16}$ Excluding the Bolivarian Republic of Venezuela and Mexico, because the former has exports that are highly concentrated in oil, and the latter is integrated into extraregional value chains, basically with the United States, in its maquila strategy.

17 In the case of Castilho's study (2012), the region means LAIA.
} 
The northern maquila industry receives inputs from the United States itself (with increasing flows also from Asia in recent times); and the finished goods are destined mainly for the United States or, at times of more intense competition, for markets elsewhere.

Based on the European example, Dullien (2010) notes that the most successful cases of production integration involve countries that are included in the production networks of a larger number of sectors, which therefore have a more diversified production structure. The author also notes greater production integration among countries with higher and more similar relative development levels. Furthermore, a dynamic analysis of the changes that occurred in Europe between 2000 and 2010 shows that production integration was driven by the interests of large industries (especially German ones), which outsourced their production to countries on the European periphery. Thus, the experience of European production integration again shows that integration reflects the production structure.

The reality in other regions reinforces the thesis that the weakness of regional integration in Latin America mainly reflects the commodity export production structures that deepened in the early twenty-first century, in the case of the South, or the reproduction of the maquila strategy in the North, which intensified the development of value chains integrated with those of the United States. Thus, the lack of structural change towards greater industrial diversification, as opposed to the production of commodities, in the early twenty-first century largely explains the constraints on regional trade and production integration, despite the political will that exists to construct it.

Considering regional integration requires thinking about structural change. Moreover, in periods of rising commodity prices, commodity-related assets become relatively more profitable than other activities, particularly more knowledge- and technology-intensive ones (ECLAC, 2012). Commodity boom periods, such as the early twenty-first century, strongly attract private investment into primary activities. Sectoral and macroeconomic policies need to be better coordinated at the national and regional levels, in order to generate economic incentives to elicit structural change and consolidate a more integrated regional trade and production space. ${ }^{18}$ The commodity cycle ended without a regional market consolidating strongly enough to achieve self-sustaining growth; external vulnerability was clearly revealed, and progressive projects in the region came under threat, even jeopardizing the social progress achieved in the early years of the century.

\section{Final remarks}

This article has addressed a number of aspects of regional integration, taking into account the changes that have occurred at the centre of the international economy, together with the heterogeneity of Latin America and the way in which the region's production structures reproduced themselves in the early twenty-first century. Although the expansion of international liquidity and the rise in commodity prices in the early part of the century eased Latin America's external constraint, these same factors provided a strong incentive for the maintenance of existing production structures (or even for reprimarization), which proved stronger than the efforts made by some countries to formulate industrial diversification policies.

Faced with this reality of production structures in the early twenty-first century, the article began by describing a new regional order in Latin America, fostered by a political moment characterized by the emergence of left and centre-left governments, dubbed the "pink tide". This process gave rise to a new Latin Americanist regional order that was different from the Pan-Americanism prevailing earlier, which, however, lacked homogeneous strategies.

\footnotetext{
18 The difficulty in furthering regional integration is also explained by the fragility of the industrial policies implemented; but that goes beyond the scope of this article. For the Brazilian case, see Carneiro (2017) and Mello and Rossi (2017). A number of industrial policy weaknesses, in adverse macroeconomic contexts, obstructed a process of structural change that would have led to greater regional integration. This reinforces the view that the economic incentives for reproducing existing structures outweighed forces for structural change.
} 
The article then described the transformations that have occurred at the centre and, in particular, the way in which the new central player in the international economy, China, developed a particular centre-periphery relationship with Latin America. This involves an asymmetrical form of bilateral trade, in which the region imports industrialized products and exports commodities. It also noted that Chinese direct investment flows into the region were also strategically targeted on raw materials. In addition to this asymmetry, which is reminiscent of the classic centre-periphery arguments of the twentieth century, additional features were observed in the rise of China and the transformation of the centre of capitalism, particularly the dynamics of commodity prices and those of manufactures.

It was found that, on the one hand, the dynamics of the new centre, of which China is a constituent part, eased external constraints and produced spillovers to the economies of the region: but on the other hand, it also encouraged the reproduction of existing production structures, created new difficulties for industrialization strategies and deepened extraregional engagement. Thus, absent structural change, regional integration remained constrained.

\section{Bibliography}

Aglietta, M. (2006), "The future of capitalism", The Hardship of Nations: Exploring the Paths of Modern Capitalism, B. Coriat, P. Petit and G. Schméder (eds.), Cheltenham, Edward Elgar.

Aglietta, M. and A. Rebérioux (2005), Corporate Governance Adrift: a Critique of Shareholder Value, Cheltenham, Edward Elgar.

Almeida, P. R. (2004), "Uma política externa engajada: a diplomacia do governo Lula", Revista Brasileira de Política Internacional, vol. 47, No. 1.

Amorim, C. (2005), "Política externa do Governo Lula: os dois primeiros anos", Análise de Conjuntura OPSA, No. 4, University Research Institute of Rio de Janeiro (IUPERJ), Cândido Mendes University (UCAM).

Bastos, P. P. (2012), "A economia política da integração da América do Sul no mundo pós-crise", Observatório da Economia Global. Textos Avulsos, No. 10, Institute of Economics (IE), Center for Studies of Current Trend and Economic Policy (CECON), State University at Campinas (UNICAMP).

Belluzzo, L. G. (2006), "As transformações da economia capitalista no pós-guerra e a origem dos desequilíbrios globais", A supremacia dos mercados e a política econômica do governo Lula, R. Carneiro (org.), São Paulo, Editora Unesp.

(2005), "Prefácio à edição brasileira", A finança mundializada: raízes sociais e políticas, configuração, consequências, F. Chesnay (ed.), São Paulo, Boitempo.

(1997), "Dinheiro e as transfigurações da riqueza", Poder e dinheiro: uma economia política da globalização, M. C. Tavares and J. L. Fiori (orgs.), Petrópolis, Editora Vozes.

Bielschowsky, R. (2016), "Fifty years of ECLAC thought: a review", ECLAC Thinking: Selected Texts (1948-1998) ", Santiago, Economic Commission for Latin America and the Caribbean (ECLAC)/ Fondo de Cultura Económica.

(2013), "Introdução ao estudo sobre padrões de desenvolvimento em 13 países - esquema analítico", Padrões de desenvolvimento econômico (1950-2008): América Latina, Ásia e Rússia, vol. 1. Centre for Strategic Management and Studies (CGEE).

Calixtre, A. and P. Barros (2011), "Além da circunstância: caminhos da integração regional sul-americana - do MERCOSUL à UNASUL", Governança global e integração da América do Sul, R. V. Viana, P. S. Barros, and A. B. Calixtre (orgs.), Brasilia, Institute of Applied Economic Research (IPEA).

Carneiro, R. (2017), "Navegando a contravento: uma reflexão sobre o experimento desenvolvimentista do Governo Dilma Rousseff", Texto para Discussão, No. 289, Institute of Economics (IE), State University at Campinas (UNICAMP).

(2007), "Globalização e integração periférica", Texto para Discussão, No. 126, Institute of Economics (IE), State University at Campinas (UNICAMP).

(2006), "Introdução", A supremacia dos mercados e a política econômica do governo, R. Lula Carneiro (org.), São Paulo, Editora Unesp.

Carneiro, R. and others (2015), "The Fourth Dimension: derivatives and financial dominance", Review of Radical Political Economics, vol. 47, No. 4. 
Castilho, M. (2012), "Comércio internacional e integração produtiva: uma análise dos fluxos comerciais dos países da ALADI", Texto para Discussão, No. 1705.

Cesa-Bianchi, A. and others (2011), "China`s emergence in the world economy and business cycles in Latin America", Discussion Paper Series, IZA, No. 5889.

Chesnais, F. (2016), Finance Capital Today: Corporations and Banks in the Lasting Global Slump, Historical Materialism Book Series, Boston, Brill.

(2005), "O capital portador de juros: acumulação, internacionalização, efeitos econômicos e políticos", A finança mundializada: raízes sociais e políticas, configuração, consequências, F. Chesnais (ed.), São Paulo, Boitempo.

(2003), "A 'nova economia': uma conjuntura própria à potência econômica estadunidense", Uma nova fase do capitalismo?, F. Chesnais and others (eds.), São Paulo, Xamã.

(1996), A mundialização do capital, São Paulo, Xamã.

(1995), "A globalização e o curso do capitalismo de fim-de-século", Economia e Sociedade, vol. 5.

Chiliatto-Leite, M. V. (2017), "Integração constrangida na América Latina: velhos e novos problemas do subdesenvolvimento no início do século XXl”, Ph.D. thesis, Institute of Economics (IE), State University at Campinas (UNICAMP).

Davies, K. (2013), "China investment policy: an update", OECD Working Papers on International Investment, No. 01.

De Conti, B. and N. Blikstad (2017), "Impactos da economia chinesa sobre a brasileira no início do século XXI: o que querem que sejamos e o que queremos ser", Texto para Discussão, No. 292, Institute of Economics (IE), State University at Campinas (UNICAMP).

Dullien, S. (2010), "Integração produtiva na União Européia: uma perspectiva alemã”, Integração Produtiva - caminhos para o Mercosul, Série Cadernos da Indústria ABDI, vol. XVI, Brasilia.

Duménil, G. and D. Lévy (2005), "O neoliberalismo sob a hegemonia norte-americana”, A finança mundializada: raízes sociais e políticas, configuração, consequências, F. Chesnais (org.), São Paulo, Boitempo.

Durán Lima, J. and D. Zaclicever (2013), "América Latina y el Caribe en las cadenas internacionales de valor", International Trade series, No. 124 (LC/L.3767), Santiago, Economic Commission for Latin America and the Caribbean (ECLAC).

ECLAC (Economic Commission for Latin America and the Caribbean) (2016a), Horizons 2030: Equality at the Centre of Sustainable Development (LC/G.2660/Rev.1), Santiago.

(2016b), Latin America and the Caribbean in the World Economy. The region amid the tensions of globalization, 2016 (LC/G.2697-P), Santiago.

_-(2016c), Relaciones económicas entre América Latina y el Caribe y China: oportunidades y desafios (LC/L.4241), Santiago.

(2012), Structural Change for Equality: An integrated approach to development (LC/G.2524(SES.34/3)), Santiago.

(1994), Open regionalism in Latin America and the Caribbean:economic integration as a contribution to changing productions patterns with social equity, ECLAC Books, No. 39 (LC/G.1801/Rev.1-P), Santiago.

Epstein, G. (2001), "Financialization, rentier interests, and central bank policy", unpublished.

Gala, P., I. Rocha and G. Magacho (2018), "The structuralist revenge: economic complexity as an important dimension to evaluate growth and development”, Brazilian Journal of Political Economy, vol. 38, No. 2.

Gallagher, K. (2016), The China Triangle: Latin America's China Boom and the Fate of Washington Consensus, New York, Oxford University Press.

Gallagher, K. and R. Porzecanski (2010), The Dragon in the Room: China and the Future of Latin American Industrialization, Palo Alto, Stanford University Press.

Gallagher, K., A. Irwin and K. Koleski (2012), The New Banks in Town: Chinese Finance in Latin America, Inter-American Dialogue.

Guttmann, R. (2008), “Uma introdução ao capitalismo dirigido pelas finanças”, Novos estudos-CEBRAP, vol. 82.

Hausmann, R. and others (2011), The Atlas of Economic Complexity: Mapping Paths to Prosperity, Cambridge, Center for International Development, Harvard University.

Hiratuka, C. and S. Cunha (2011), "Qualidade e diferenciação das exportações brasileiras e chinesas: evolução recente no mercado mundial e na ALADI", Texto para Discussão, No. 1622.

Hiratuka, C. and F. Sarti (2015), "Transformações na estrutura produtiva global, desindustrialização e desenvolvimento industrial no Brasil: uma contribuição ao debate”, Texto para Discussão, No. 255, State University at Campinas (UNICAMP).

Lall, S., J. Weiss and H. Oikawa (2005), "China's competitive threat to Latin America: an analysis for 1990-2002", Oxford Development Studies, vol. 33, No. 2. 
Medeiros, C. A. (2015), Inserção externa, crescimento e padrões de consumo na economia brasileira, Brasilia, Institute of Applied Economic Research (IPEA).

(2010), "Modelos alternativos para la integración sudamericana", Integración regional en América Latina: desafios y oportunidades, Geneva, United Nations Conference on Trade and Development (UNCTAD). (2006), "A China como um duplo pólo na economia mundial e a recentralização asiática", Revista de Economia Política, vol. 26, No. 3.

(1999), "Economia e política do desenvolvimento recente na China", Revista de Economia Política, vol. 19, No. 3.

Mello, G. and P. Rossi (2017), "Do industrialismo à austeridade: a política macro dos governos Dilma”, Texto para Discussão, No. 309, Institute of Economics (IE), State University at Campinas (UNICAMP).

Milberg, W. (2004), "The changing structure of international trade linked to global production systems: what are the policy implications?", Working Paper, No. 33.

Mota Veiga, P. and S. P. Ríos (2007), "O regionalismo pós-liberal, na América do Sul: origens, iniciativas e dilemas", International Trade series, No. 82 (LC/L.2776-P), Santiago, Economic Commission for Latin America and the Caribbean (ECLAC).

Natanson, J. (2009), La nueva izquierda: triunfos y derrotas de los Gobiernos de Argentina, Brasil, Bolivia, Venezuela, Chile, Uruguai y Ecuador, Buenos Aires, Debate.

Ocampo, J. A. (2007), "The macroeconomics of the Latin American economic boom", CEPAL Review, No. 93 (LC/G.2347-P), Santiago, Economic Commission for Latin America and the Caribbean (ECLAC), December.

OECD (Organization for Economic Cooperation and Development) (2008), OECD Investment Policy Reviews. China 2008: Encouraging Responsible Business Conduct, Paris, OECD Publishing.

Palley, T. (2007), "Financialization: What it is and why it matters", Working Paper, No. 525, Levy Economics Institute.

Palma, G. (2005), "Four sources of 'De-Industrialisation' and a new concept of the 'Dutch Disease'”, Beyond Reforms: Structural Dynamics and Macroeconomic Vulnerability. J. A. Ocampo (ed.), New York, Stanford University Press/World Bank.

Plihon, D. (2005), "As grandes empresas fragilizadas pelas finanças", A finança mundializada: raízes sociais e políticas, configuração e conseqüências. F. Chesnais (ed.), São Paulo, Boitempo Editorial.

Prebisch, R. (2016), "The economic development of Latin America", ECLAC Thinking: selected Texts (1948-1998), R. Bielschowsky (comp.), Santiago, Economic Commission for Latin America and the Caribbean (ECLAC).

Rocha, I. L. (2015), Essays on Economic Growth and Industrial Development: A Comparative Analysis between Brazil and South Korea, Cambridge University.

Rocha, M. (2015), "Transformações produtivas e patrimoniais no Brasil pós-crise", Dimensões estratégicas do desenvo/vimento brasileiro. Brasil: em busca de um novo modelo de desenvolvimento, vol. 4, Brasilia, Centre for Strategic Management and Studies (CGEE).

Rodrik, D. (2016), "Premature deindustrialization”, Journal of Economic Growth, vol. 21, No. 1.

Rohter, L. (2005), "With new chief, Uruguay veers left, in a latin pattern", New York Times, 1 March.

Rowthorn, R. and J. Wells (1987), De-industrialisation and Foreign Trade, Cambridge, Cambridge University Press.

Tavares, M. C. and L. E. Melin (1997), "Pós-escrito: a reafirmação da hegemonia norte-americana", Poder e dinheiro: uma economia política da globalização, M. C. Tavares and J. L. Fiori (orgs.), Petrópolis, Editora Vozes.

Teixeira, R. A and W. A. Desiderá Neto (2012), "La recuperación del desarrollismo en el regionalismo Latinoamericano", Perspectivas para la Integración de América Latina, W. A. Neto and R. A. Teixeira (orgs.), Brasilia, Institute of Applied Economic Research (IPEA).

UNCTAD (United Nations Conference on Trade and Development) (2011), Price Formation in Financialized Commodity Markets: The Role of Information, Geneva. 